\title{
Küüditamise lood: Siber 1941
}

Pille Kippar

\begin{abstract}
Teesid
President Lennart Meri, ajaloolane ja kirjanik, kuulutas 2001. aasta kevadel, esimese suure nõukogude küüditamise 60 . aastal, välja küüditamismälestuste kogumise kooliõpilaste hulgas. Ametist lahkuva presidendi idee oli, et meie lastel, uuel põlvkonnal, on vaja saada elavaid mälestusi oma vanavanematelt, et õpilased ise õpiksid tundma ja kirjutaksid üles ajalugu: oma pere, oma rahva, oma kodumaa ajalugu.

Küüditamismälestused "Vaikimise väraval" avaldab 50 õpilase kirjapanekuid. Need on tollaste ellujäänud laste või noorte inimeste Siberimälestused - sellised, nagu nad lastele meelde jäid. Kirjeldatakse valusaid isiklikke üleelamisi, üldistusi on vähem. Oma pere ja Eesti riigi eest hoolt kandvaid täiskasvanuid tabas küüditamine veel raskemini.

Märksõnad: nälg ja surm, kaebamine ja nuhkimine, vene keele oskus, oma põllulapp, eestlaste käsitöö, töö kvaliteet, kool, ameti õppimine, Stalini surm, sõja lõpp, kirjad ja pakid kodumaalt, tagasi Siberisse, vabastamine/vabanemine, kodumaa ei võta vastu
\end{abstract}

Väljarändamine, küüditamine ja okupatsioon on puudutanud eestlasi ja Eestit sajandeid; nendest jutustamine on ikka olnud päevakorral. Peredes ja tuttavate ringis räägiti maailmameredele purjetanud madrustest ja kaptenitest, Venemaa avarustele tasuta maad otsima läinud talumeestest, Siberisse saadetud vastuhakkajatest ning meie maad ihkavatest vallutajatest - tulgu nad idast või läänest (vt nt Kulu 1992). Perepärimus, tuttavate ja sugulaste mälestused olid justnagu oma asi ja ei kuulunud laiemale ringkonnale. Kuna sellised lood muutusid ja täienesid pidevalt, siis varasematel aegadel neid rahvaluuleks ei peetud ja järjekindlalt üles ka ei kirjutatud. Pärimuslugusid jõudis siiski ajakirjandusse, neid kasutati kirjandusloomingus; üht-teist leidub ka arhiivides. Võõra võimu all elaval rahval peab alati olema piir teada või häirekell ärkvel - rääkida tohib vaid seevõrra, et enesele ja lähedastele kahju ei tee! Paljud lood, mis tundusid kahtlasena - kas tohib või ei tohi, kas on keelatud või ei, - jäid vaid oma pere teada ja ununesid nende jutustajatemäletajate lahkumisega.

20. sajandi II poolel, eriti pärast Teist maailmasõda, mis paljud rahvad ja rahvakillud oma elupaikadest minema paiskas, hakati mitmel pool maailmas oma päritolule ja juurtele tähelepanu pöörama. Nii ka meil.

http://haldjas.folklore.ee/tagused/nr27/kippar.pdf 
Eestimaa rahvastiku üldarv 1939. a oli 1134 000. Samal sügisel registreeris Väliseesti kongress ca 176000 väliseestlast (Raag 1999).

Eriti suured muutused toimusid II maailmasõja käigus ja pärast seda. Eesti rahvastikukaotusi on arvestatud mitmete kategooriate kaupa: vangistatud, hukatud, küüditatud, põgenenud ja maha lastud Saksa või Vene okupatsioonivõimude ajal, sõjas langenud ühel või teisel poolel. Kõige selle tõttu kaotasid eestlased ligi $20 \%$ oma rahvast.

Esimese Vene okupatsiooni ajal 1941. aastal küüditati Eestist Siberisse ca 10000 inimest (Õispuu 2001: 304). 1949. a oli see arv suurem: küüditamisnimekirjadesse oli kantud ligi 30000 , nendest viidi sel märtsikuul tegelikult 21251 . Paljud pered viidi hiljem (Õispuu 1999: 10). Mõlema suure küüditamise eesmärgiks oli eeldatava poliitilise vastase likvideerimine koos juurtega ja algas SuurVene uute okupeeritud piirialade ümberrahvastamine (Õispuu 2001: 28)

Sõja ajal ja pärast sõda (1943-1944) põgenes Saksamaale ja Rootsi ning sealt edasi mujale Läände 70 000-75 000 inimest (Raag 1999). Raimo Raag märgib, et 1950. a oli idas ja läänes kokku ca 170000 väliseestlast (Raag 1999: 76).

Eesti riik kaotas peale eestlaste veel 16000 baltisakslast + nendega koos lahkunud ca 4000 eestlast (Hitler kutsus aarialased 1939. aastal Saksamaale (Raag 1999) ning 6500 eestirootslast (lahkusid 1942-1944 sõja ajal Rootsi). Sõja-aastate kaotusi on uurinud mitmed teadlased (nt Kippar 1998; Paavle 2002; Õispuu 1999, 2002).

Pärast sõda (1945) oli Eesti kogurahvastik 854 000, eestlasi 831 000 ning mitte-eestlasi 23 000, st eestlaste osa 97,3\% (Viikberg 1999: 129).

Huvi suguvõsade ja oma päritolu vastu levis 20. sajandi II poolel Eestis esmalt väliseestlaste mõjul, kes võõrsile sattunutena oma juuri ja minevikku otsisid. Tähelepanu rahva mineviku ja mälestuslugude vastu oli tekkinud siiski juba enne sõda, aga alates 1980ndatest hakati peremälestusi ja kireva saatusega inimeste elulugusid koguma süstemaatiliselt. Uue, laiema kogumisaktsiooni eesotsas seisis Eesti Muinsuskaitse Selts. 1988. aastal, täpselt 100 aastat pärast eesti rahvaluulekoguja Jakob Hurda suure üldrahvaliku rahvaluule kogumistöö algust (1888) alustati uut mälestuste kogumise hoogtööd. Peatähelepanu pöörati nüüd suurtele muudatustele rahva elus, eriti eestlaste vägivaldsele Siberisse küüditami- 
sele 1941 ja 1949 ja seal toimetulekule, samuti põgenemisele Läände. Kõikidel teemadel sai vabalt rääkima hakata alles pärast Nõukogude Liidust väljaastumist ja Eesti iseseisvuse taastamist (1991).

Tartu Kirjandusmuuseumi on kogunenud kümneid tuhandeid lehekülgi ja palju helilindistatud tunde mälestuste ja elulugude kirjapanekuid. Mälestuskirjutusi ja -raamatuid tuleb aina juurde (Eesti elulood 1997a, 1997b, 1999).

President Lennart Meri, ajaloolane ja kirjanik, kuulutas 2001. aasta kevadel, esimese suure Nõukogude küüditamise 60. aastal, välja küüditamismälestuste kogumise kooliõpilaste hulgas. Ametist lahkuva presidendi idee oli, et meie lastel, uuel põlvkonnal, on vaja kuulda elavaid mälestusi oma vanavanematelt, et õpilased ise õpiksid tundma ja kirjutaksid üles ajalugu: oma pere, oma rahva, oma kodumaa ajalugu. Kuna arhiivides oli juba materjali rohkesti, siis arvati, et ehk enam uut materjali ei tule. Saadud tulemus ületas ootused. Ilmus raamat 50 õpilase kirjapanekuga.
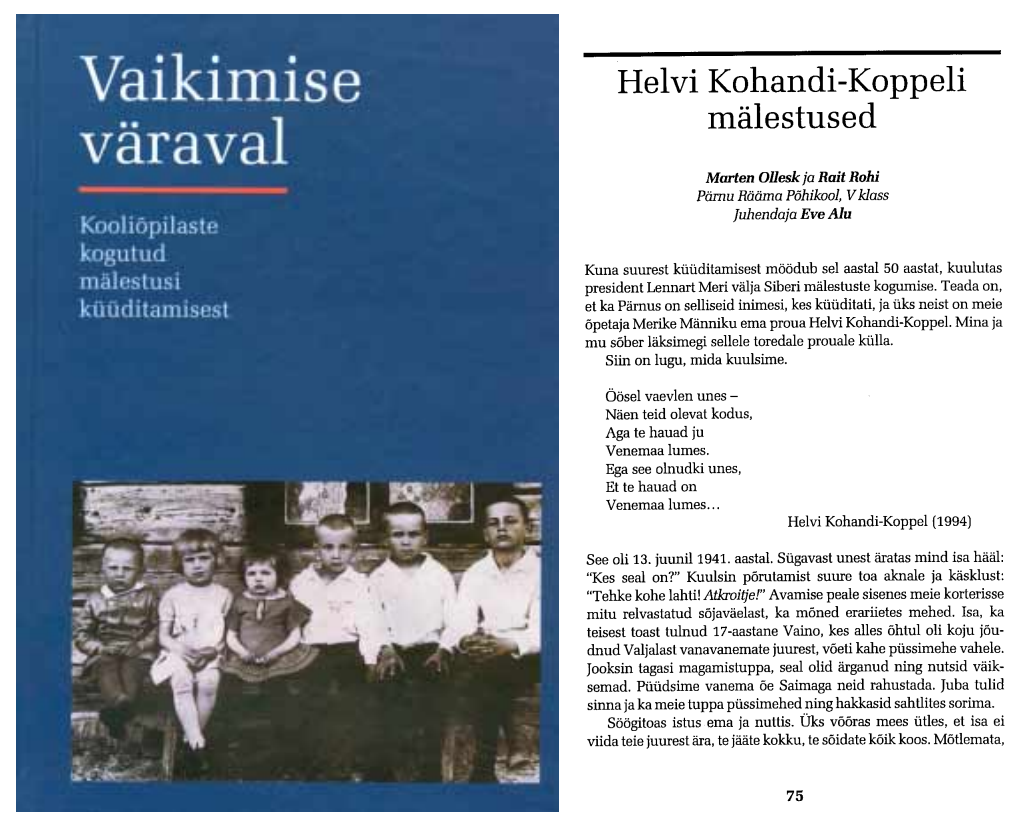
Selles raamatus on tollaste ellujäänud laste või noorte inimeste Siberi-mälestused - sellised, nagu nad lastele meelde jäid. Kirjeldatakse valusaid isiklikke üleelamisi, üldistusi on vähem. Oma pere ja Eesti riigi eest hoolt kandvaid täiskasvanuid tabas küüditamine veel raskemini. Üleskirjutuste hulgas on 1949. aasta küüditamise materjale rohkem ja teemadki nendes pisut teistsugused: ikkagi natuke vähem valusad.

Järgnevalt käsitlen lähemalt ainult 1941. aasta 14. juunil küüditatud laste ja noorte mälestusi sellest raamatust. Näidetena kasutan peamiselt Saaremaalt 14. juunil 1941 Siberisse küüditatud suure 7lapselise pere tütre, proua Helvi Kohandi-Koppeli mälestusi.

14. juuni on Eesti Vabariigis kuulutatud leinapäevaks. Varahommikul aastal 1941 peatusid paljude eesti haritumate ja jõukamate perede uste ees veoautod vene sõdurite ja kohalike küüditajatega. Nõuti sisselaskmist.

Korraga valitses tubades tohutu segadus. Lapsed nutsid, sõjaväelased otsisid midagi ning loopisid isa riiuleist raamatuid. Mõned võõrad tõmbasid vooditekke nööriga puntrasse. Ema oli toolilt tõusnud ja ladus kohvrisse naftaliinilõhnalisi lõngavihte. Isa pakkis midagi püssimeeste pilgu all. Sahvrist visati ühte kasti suitsuliha ja poolik hernekott. Ka käsiõmblusmasin mahtus sinna. Eriti valvsalt jälgiti vanemat venda, kui ta oma lauasahtlist võttis mõned õpikud või sulges klaverikaane ja pani portfelli mõni tund tagasi mängitud noodid. "Bõstreje! Bõstreje!-Kiiremini! Kiiremini!” Siis ma veel ei teadnud ega suutnud mõista, et on olemas asju, mida saab teha ainult öö musta katte varjus. [---]

Ema hoidis süles sel päeval kaheaastaseks saavat Mallet. Kuueaastane Lille ja üheksane Helle olid veel unehämused. Üheteistkümnene Arvi ja mina (Helvi) istusime juba veoautos ja hoidsime käes oma isiklikke asju. Viieteistkümnene õde Saima oli kuidagi sügavalt mõtteis. Kuigi oli südasuvi, oli ema käskinud talvemantlid selga panna; hoolimata sellest tundsin jahedust terves ihus ja isegi veel sügavamal.Vend Vaino (17) kükitas kahvatuna autokasti nurgas. Isa pü̈̈dis hoida pere ligi, kuid üks püssimeestest oli võtnud ta erilise valve alla. [---] 
Vanematel inimestel oli vist nü̈d suund selge. Minuealised (lapsed) ei tajunud kogu toimuva tõelisust. Kohati oli isegi põnev.

Helvi Koppel, lk 76/77

Pere äraviijateks 14. juuni öösel olid kaks venelast ja üks eestlane, kes käis emal kogu aeg revolvriga taga, ise värisedes nagu haavaleht, sest ta ei osanud vene keelt. Ema oli neile tõlgiks. Enne äraviimist toimus ka läbiotsimine - kõik puistati laiali. Taheti just isa ja poolvenda; viimast peeti ekslikult üleval korrusel elavaks miilitsaks.

Keegi ei osanud seda ette näha, et viiakse ära ka naised ja lapsed, arvati, et viiakse ainult mehed. Isa koos poolvenna Lembituga põgenes järve taha tallu ning käskis ka 7-aastasel Endlil seda teha. Nende perekonnatuttav ämmaemand Alide Toom arvas koguni, et naisi ja lapsi võeti pantvangiks, kuna mehi ei saadud kätte, mille peale isa tuli oma naiivsuses, mõeldes lastele, välja ning andis ennast ise üles.

Rongi marsruut: Võru - Pihkva - Petseri (pikk peatuskoht) - Kirov - Perm - Sverdlovsk - Kurgan-Omsk - Kargat (ümberpaigutus elevaatoritesse) - Novosibirsk (inimesed paigutati ümber laevadele) - Obi jõgi-Kargasok-Nedostupnõi (viimane peatuspaik).

Endel Muuga, lk 51

Sel varahommikul ja päeval viidi ette hoiatamata Eestist Siberisse ca 10000 eestlast. Kavas olnud ka teine ja kolmas küüditamise voor, aga vahepeal (21.06.1941) algas sõda. Nüüd tagasi Saaremaale.

Kail toimetavate ja istuvate inimeste vahel kõndis tüse tumedate vurrudega mees, lai rihm kinni hoidmas tolleaegse miilitsasineli musti hõlmu. Pidevalt kamandas ta inimesi kiirustama, nagaaniga käsi energiliselt näitamas laeva suunas. Kohati tuli tal astuda üle ajutiste toidulaudade ja magavate laste. Kuulsin ema sosistavat: "See on miilitsaülem, endine lihunik M.” Nüüd oli ta nägu minulegi tuttav. Olin näinud teda suure kirvega lihakehi raiumas, verine põll ees. Korraga seisis ta meie ees ja käratas: "Mida sa, Koppel, viivitad, hakka laevale astuma!"

Helvi Koppel, lk 77 
Mälestuste järgi oli küüditajaid mitmesuguseid. Mõni ainult kiirustas ja sõimas, teine aitas ehmatusest ja tardumusest üle saada, asju pakkida. Kui deporteerimise otsus ette loeti, said inimesed teada, mis teekond ees ootab, teinekord seda ei avaldatud. Mõnel perel oli kasu umbkeelsest vene sõdurist, kes,Venemaa ja Siberi olusid tundes, pani poolvägisi kaasa tööriistu ja majapidamistarbeid. Kõige raskemaks kujunes selliste perede saatus, kellel kodus mingisuguseid tagavarasid polnud või kes, olukorda absurdseks pidades, ainult natuke suveriideid kaasa võtsid.

Esimesel kahel aastal surid ära kõik need, kes nari peal ohkasid, et mis saab, mis saab, kuidas ma koju saan jne. Elujõulisemad inimesed, kes korjasid heinu ja tegid puid, jäid ellu. Surdi ära eeskätt sellepärast, et langeti masendusse ja oldi ükskõiksed.

\section{Endel Muuga, lk 52}

Marie Erits, rahvaluuleuurija ja eeposte tõlkija dr August Annisti õde, pannud valge põlle ette ja seadnud tärgeldatud rätiku pähe ning läinud naeratades õue, et oma eeskujulikus talus järjekordset ekskursiooni vastu võtta, kui selgus, et saabusid hoopis küüditajad ja viisid pererahva Siberisse.

Esimene siht oli raudteejaam, kus juba ootasid sisseehitatud naridega loomavagunid. Mehed suunati kohe eraldi vagunitesse. Sõideti itta.

Pool kaks päeval läks rong Narva raudteejaamast liikuma. Samal hetkel hakkas Aleksandri kiriku kell lööma matusekella. Kas oli keegi julge seda teinud või maeti kedagi, aga oli selline kokkusattumus. Kõik vangid nutsid.

Leida-Johanna Savi, lk 58

Helvi Koppel meenutab:

Liikus kuuldus, et osa mehi on rongilt eemaldatud. Naised saatsid kirjakesi vagunist vagunisse. Isegi konvoiga. Ema sai teada, et Koppel (meie isa) on veel meeste vagunis, ja muutus reipamaks, kui ütles, et neil mõlemal on pedagoogiline haridus, mõlemad valdavad vene keelt ja küllap jätkub ka Venemaal õpetajale tööd. Ka meile, lastele, mõjus ta optimism soodsalt. 
Aga kui järgmises peatuses Vologda lähistel toodi meeste poolelt meie vagunisse vend Vaino, muutus ema murelikuks. Ta palus üht vahisõdurit hankida mingit teavet meeste kohta. Kui saabus järgmine peatus, paotas see sõdur vaguniust ja teatas, et meeste vagunit ei ole enam ešelonis. Kuhu meid siis ikkagi viiakse? [---]

1944. aasta suvel sai ema läbi mitmekordse kirjavahetuse teate, et meie isa oli surnud 1942. aasta veebruaris. Vaikiva ja kaamena võttis ta selle sõnumi vastu. Surmaeelsel ja järjekordse edasikü̈̈ditamise ôhtul olevat isa oma saatusekaaslastele öelnud: "Uskuge, mehed, meid viiakse kindlasti perekondade juurde...” (Belajas ja Sinegorjes elanud eesti perede isadest pääses laagritest elusana kolm meest...)

\section{Helvi Koppel, lk 77-81}

Kuupikkust, lõputute ootamistega, vähese vee ja toiduga ning lausa ilma sanitaartingimusteta reisi Siberisse kinnistes loomavagunites, seejärel pargastel, lotjadel, siis hobuste või härgadega ja jalgsi mäletavad ja kirjeldavad kõik toonased lapsed. Nädala pärast algas sõda.

Väga täpselt ja hästi mäletatakse pikka reisi, paiku ja kohanimesid, kirjeldatakse vene kerjuslapsi, väga vaeseid ja kitsaid maju, kus tuli elada koos kohalikega. Sageli olid need vene väljasaadetud, kõige töökamad ja targemad venelased - küüditatud taigasse aastatel 1925, 1932, 1937. Ka Eestist pärit ümberasujaid/küüditatuid viidi korduvalt paigast teise.

Rahvast hoiatati vereimejate-orjapidajate eest, kes olevat karistuse ära teeninud. Meid käidi isegi katsumas, sest enamikul eesti naistel olid peas elektrilokid ja nad pidasid seda meie rassi tunnuseks.

Leida-Johanna Savi, lk 59

Tollaste laste mälestustes on neljakümnendatest aastatest kolm valusat intensiivset teemat: nälg, surmad ja ema raske töö. Toitu ei olnud, üldse ei olnud. Üks väike poiss küsinud emalt, kuidas ta kodus Saaremaal oskas head süüa teha, aga siin sugugi ei oska. Raskel tööpäeval said tööinimesed 400-600 g vesist leiba päevas, kodused ja lapsed $200 \mathrm{~g}$ või mitte midagi. Muud toitu ei olnud. Kusagilt midagi saada polnud võimalik. Kui leiba üldse ei olnud, anti 
mõnikord natuke kaerakooki - see oli midagi tänapäevase loomajõusööda taolist.

Raskeks muutus nende perede elu, kes olid teel oma vähese pagasi kaotanud või ei saanud seda kaasa võttagi. Ka meie suurel perel olid vaid voodiriided ja natuke villast lõnga. Lõngast kudus ema kõigile valged põlvikud ja kindad. Aga asju toiduainete vastu vahetamiseks, mis paljusid peresid päästis, meil ei olnud. Ei olnud ka talvejalatseid.

\section{Helvi Koppel, lk 78}

Kõht oli küll pidevalt tühi, aga enam polnud niisugust nälga nagu esimesel aastal. Ema jätkutas ikka kartuleid nii, et saime iga päev suppi. Et supp ei oleks liiga vesine, riivisime osa kartuleid, siis sai leem kliistrine, ikka toekam. Lastel oli raske nälga taluda.

Tõenäoliselt oli mu kiiresti kasvaval vennal toiduvajadus suurem kui minul. Enne jõule küsisin temalt, mida ta pühadeks tahaks, kui sü̈̈a oleks küllalt. Ta vastas: "Päts leiba." Küsisin uuesti, et kui kõht oleks täis. Tema hakkas nutma ja ütles, et ikka päts leiba. Pidevalt tühi kõht ei lubanud tal ka mõtetes millestki muust unistada.

Asta Rohtla, lk 66

Eriti emotsionaalsed on toonaste laste mälestustes surmad. Neid oli lõputult ja igas peres.

Algas suremine. Kõigepealt surid beebid. Surid kõik alla 2-aastased lapsed peale ühe. 9-kuune Viiu jäi elama, sest saatuse tahtel sai tema ema korteri majja, kus asus meierei ning ta sai iga päev natuke lõssi. Osa inimesi ei tulnud šokist välja ja surid paari kuu jooksul. Enamasti olid need väga intelligentsed täiskasvanud, kes ei näinud enam elu mõtet. Nad surid peaaegu perekonniti. [---] Esimesest aastast on meeles vaid lõputud kirstud, surnud inimesed puusärgis, nälg ja nutt. Vene naiste suur ühine halamine, sest enamiku sõttaläinud meeste kohta tuli surmateade.

Need täiskasvanud, kes jäid elama, pidid minema metsatööle. Nii ka meie ema. Naised ilma soojade riiete ning jalatsi- 
teta ning ilma oskusteta pidid langetama puid. Ema külmetas metsatööl ära oma varbad, nii et need hakkasid mädanema, ja tõmbas lahti ühe neeru.

Olime kõik näljas. Suurvee tõttu pandi kartulid maha alles juulis ja saak oli ülikehv. Meie ei saanud sedagi - polnud ju maad. Saime igaüks 200 grammi leiba ja kõik. Muid toiduaineid ei olnud. Suvel sõime maltsasuppi.

Talv oli väga raske, aga jäime ellu.

\section{Asta Rohtla, lk 65-66}

Tuli raske talv 1941/42. Tuli sügava lume ja pakasega. Ema hingevalu võis küll ränk olla, kui ta nägi oma kõhnuvaid lapsi. Eriti muutus Lille, kes kohe algul loobus võõramaisest toidust. Kord kuus käis Sinegorjest tervist kontrollimas velsker-akušöor, kellel peale lilla lahuse muud ravimit kaasas ei olnud ja kelle visiididki seisnesid põhiliselt üle barakiukse vaatamises. Hilissügisel, kui ema tuli töölt paljajalu läbi jääkirmega kaetud veelompide, haigestus ta raskelt, aga abi ei olnud kusagil.

Lille olukord halvenes silmanähtavalt. Ta jäi lamama ja nägi välja nagu skelett. Küllap ema tundis lapse juures juba surmahaaret, sellest ka närvivapustus, kui meid järjekordselt tulid kontrollima valgetes kasukates julgeolekumehed. Ema palvele kirjutada raskelt haigele lapsele paarsada grammi mannat või jahu, vastasid nad, et see polevat võimalik. Ema muutus näost valgeks ega saanud jätta endasse sõnu: "Surevale lapsele ei saa suur Venemaa lubada 200 g mannat, aga väike Saaremaa jõudis liha, munade, piima ja võiga toita sinna toodud 2000 vene sõdurit."

Vana-aasta õhtul tõi Kannu-ema naaberbarakist meile kruusitäie jahu ja katelokitäie kartuleid. Keetsime suppi, kuid Lille pööras näo kõrvale. Ema pani pliidisütesse ühe kartuli. Selle sõi Lille ära ja ütles siis emale: "See oli nii hea, kas saaks veel ühe...” Söed olid kustunud, ema lubas varahommikul teha pliidi alla tule ja täita lapse soovi. Hommikul Lillet enam ei olnud. Matmispaigaks sai lapike Sinegorje kontori taga. [---]

Kust võttis küll ema veel jõudu pärast nooremate tütarde kahese Malle ja kuuese Lille - kaotust organiseerida poja matmist... Vainot läksid saatma ema ja Saima ning kümmekond eesti naist. Seisime Arvi ja Hellega seni lagendiku serval, kuni Altosaare Anne kõlav lauluhääl kaugusest enam ei kostnud. 
Vaino puhkepaigaks sai samuti Semikolennõi surnuaed. Keegi eesti poistest Sinegorjes oli meisterdanud risti, millele põletatud: VAINO KOPPEL 10.01.24-25.05.42.

\section{Helvi Kohandi-Koppel, lk 80-81}

Surmaga puutusime kokku palju kordi. Esimene surm oli juba Obi jõe pargasel. Suri 3-kuune laps. Ema lootis teda korralikult matta ja ei teatanud lapse surmast valvuritele mitu päeva, hoidis teda siiditeki sees süles. Lõpuks ikkagi tuli öelda. Pargas aeti kalda äärde, püssimehed läksid laibaga kaldale. Ema tahtis kaasa minna, aga ei lubatud. Siis alustas aga keegi kiriklikku matuselaulu:

"Tähtede taga, seal paistab sul taevas..."

ja kõik ühinesid. Terve pargas laulis. Valvurid arvasid, et on ülestõus, võeti püssid õlalt ja hakati ôhku tulistama. Kuidas lapsuke maeti, ei tea keegi. Kas kaevati ka haud või jäi lihtsalt jõe kaldale?... [Pean lisama, et vene tava kohaselt oleks pidanud ema - ja ema üksi - kohe lapse suremise järel itkema hakkama. Kogu rahvas neil sellisel puhul ei laula, ka mitte matuselised. Siit siis valestimõistmine. Ja eks venelased olid ka "kurjategijate", "kurnajate" ja "vereimejatega" ära hirmutatud, kelleks ju Siberisse saadetuid ebaõiglaselt peeti.-P. K.]

Hiljem oli surma kohutavalt palju. Enne kui lapsed, surid tavaliselt nende emad, sest viimane toidupala anti lastele. Mul oli hea meel, et minu lapsed kodumaale jäid. Teadsin, et nad vähemalt ei nälgi. Ei teadnud aga seda, et Sinimägedest käis üle suur sõda, hävis mu kodu, suri mu isa ning mu lapsed, ema ja õde pidid otsima endale uue kodu. Aga nad olid ikkagi Eestimaal. [---]

Ega me ei teadnud alul, et üldse Eestist ära viiakse. Aga see eestlane, kes kaasas oli, näitas suurt inimlikkust ja küsis, et kumma vanemate juures me elame. Kuulnud, et need on minu vanemad, soovitas ta lapsed maha jätta. Ma ei tahtnud seda kuuldagi, aga siis tuli isa, vaatamata keelule, minu juurde, võttis õlgadest kinni ja ütles: "Ära võta lapsi kaasa, Leida!" Erariides mees ütles vaikselt: "Lapsed ei ela seda üle, mis teil tuleb üle elada.” Tütar oli nelja ja poole aastane, poeg 9-kuune.

Leida-Johanna Savi, lk 57, 60 
Mõni väike laps jäi veel Eestisse. Ilse Kotteri 3-nädalane poeg polnud veel küüditatavate nimistusse kantud ja ta sai poja oma õe hoolde jätta.

Venemaal, Kolpasevos sain kord kirja - tulin töölt koju ja naised ütlesid, et mulle on kiri. See oli saadetud Eestist. Meie endine teenija Miina saatis. Tema oli saanud Rootsist täditütrelt kirja ja seal oli ka pilt minu pojast Vellost, kui ta oli 2-aastane. Kirjad jõudsid meieni lahtivõetult, nii et kui ma töölt tulin, siis kõik minu toakaaslased juba teadsid, et mulle on saadetud pilt pojast. Võtsin selle pildi kätte ja mõtlesin, et vaatan erapooletult-kuidas ta mulle meeldib. Ja järsku mõtlesin - ega tal viga ei ole, nagu see polekski minu laps. Mul oli raske mõelda, et see ongi minu poeg. Ma ei jõudnud teda ju õieti tundmagi óppida. Olin kogu aeg lootnud, et ta on elus. [---]

Oma poega nägin esimest korda Tallinnas 1969. aastal suurel juubelilaulupeol. Vello oli siis 28-aastane, naist polnud veel võtnud. Õde kasvatas mu poja ameeriklaseks; ta sai ingliskeelse hariduse, eesti keelt ei osanudki. Kui me esimest korda kohtusime, ei osanud oieti rääkidagi, sest mina jälle ei osanud inglise keelt, tema aga ei teadnud vene keelest midagi. Mul oli sellestki hea meel, et ta kandis oma isa nime, kuigi Eestimaast ja eesti keelest ei teadnud õieti midagi...

\section{Ilse Kotter, 44, 50}

Töö oli seal Siberis raske ja võõras; polnud ei tööriistu, riideid ega oskust. Aga elada tuli, kes ellu jäi. Kui ema suri või haigestus ja polnud kedagi, kes lapsed oma hoolde oleks võtnud, pandi lapsed lastekodusse ja seal oli juba raske eestlaseks jääda. 1941. aasta suvel küüditatud ja Venemaal lastekodusse paigutatud Matti Päts on meenutanud oma esimesi, vaevaga kirjutatud eestikeelseid kirju kodumaale. Iga nädal tuli end meldimas käia, et pole külast lahkunud.

Parasjagu oli heinatöö pooleli. Hommikul kogunesime kontori juurde, seal ootas rahvas kahte hobuveokit, millega sõidutati tööle ja ka kulstani (toitlustusjaam) juurde. See oli majake põldude keskel, kus lõunatati ja kus oli lõuna ajal võimalik veidike puhata ning öösiti magada. Natuke eemal oli kunstlik veehoidla hobuste jaoks. Noored ja vallalised elasid kevadel ja 
sügisel kulstanis, välja arvatud laupäevaõhtuti, kui lubati külla sauna minna. Looduslikku heina niideti käsivikatiga ja riisuti käsitsi kokku, põldhein niideti kahehobuse niidumasinaga, riisuti kokku loorehaga. Inimeste toitlustamine oli kohapeal kolhoosi poolt, algaastail $600 \mathrm{~g}$ kaeraleiba päevas, juurde sai suures katlas keedetud lapšaasuppi, vahel kartuliliimu ja teinekord kaerakilet. Teevett keedeti mustsõstraokstest.

[---] Talvel kulus heina vedamiseks luhast kodukülla kaks päeva ja sellega sai ränka vaeva näha. Teele mindi varahommikul, et saada samal päeval koormad peale ja jõuda teise külla ööbimispaika. Varahommikul asuti kodu poole teele, peale lõunat jõuti koju, siis laaditi koormad maha ja teisel varahommikul jälle teele. Igal mehel oli kaks hobust, vahel ka kahe peale viis hobust. Silo valmistati heinateoga paralleelselt. Tehti looduslikust rohust. Kõik, millele vikat peale hakkas, läks siloks. Siloaugud olid kaevatud käsitsi; maapind oli hästi savine. Talvel oli siloaukude lahtiraiumine ränk töö. Pinnas oli kõvasti külmunud, silo aga mitte.

Rukist loigati meie külas sirbiga. Seoti vihkudesse ja pandi hakkidesse. Kohalikud oskasid seda tööd päris hästi, ka eesti naised, kes maalt olid pärit. [---]

Üks mahukamaid töid sügisel oli käsitsi linakitkumine. Linapeod seoti ja pandi püsti hunnikuisse 20-30 kokku, seal seisid, kuni ära kuivasid, siis kanti käsiraamidel kuhjadesse ja talvel veeti regedega majade juurde, igale perele hobusekoorem. Tuli käsitsi külmunud maapinnal põlvili maas kurikaga kolkida, kuni kuprad purunesid ja seeme pudenes.

Talvel oli väga raskeks tööks metsatöö $60 \mathrm{~km}$ kaugusel. Riigiplaan tuli täita. Naised langetasid puid. Vahel oli lumi pooleteise meetri sügavune, siis tuli puu kõigepealt lume alt välja rookida. Puud olid väga suured, ligi meetrise läbimõóduga. Hobusemehed vedasid palgid jäätee äärde platsile. Jä̈̈tee asendas Siberi taigas raudteed. Suvel raiuti sirged sihid metsa, pehmed kohad täideti. Lume peale sõideti jääkelguga jäljed sisse, pärast kasteti veega üle ja hööveldati rööpad siledaks. Hiljem seda tegevust korrati. Jääteed pidi veeti kõik palgid hobustega jõekaldale. Kevadel veetõusu ajal parvetati.

Kevadel, kui põllutööd lõpetati, korraldati igal aastal pidu. Lauale pandi ôlut ning enamikus olid kalatoidud. Väga halbadel aegadel söödi nõgese- ja maltsasuppi. 
Kuna olime suurele kodumaale mitteustavad inimesed, siis elasime järelvalve all. Komandant käis algul igal nädalal, hiljem üks kord kuus meid üle kontrollimas.

Ema, isa ja minu rännak kestis täpselt seitseteist aastatära viidi meid laupäevasel päeval 14. juunil 1941. aastal ja tagasi Järva-Jaani raudteejaama tulime 14. juunil 1958. aastal.

Ülo Aasa, lk 73/4

See oli nagu looduslik vangla ilma valvuriteta. - Mis see tähendab? - See tähendab, et ümberringi sealt läbi ei pääsenud, olid lõputud metsad ja sood. Ära oli võimalik pääseda ainult parvega mööda jõge, aga sadamas oli ju väga lihtne kinni võtta. Lennukit sõiduks ma kasutada ei saanud, sest polnud raha ega passi. Iga kuu käis NKVD komandant kontrollimas, kas kõik on kohal.

\section{Leida-Johanna Savi, lk 60}

Tasapisi kohaneti, saadeti lapsed kooli, kus see olemas oli, ja õpetaja nõus muukeelseid võtma. Eesti emadel, ka õpetajatel mitte, polnud võimalust eesti lapsi õpetada, sest igapäev tuli kolhoosis tööl käia. Õpiti ära vene keel, hariti omale maatükk kartulite ja naeriste kasvatamiseks, hangiti eluase, hiljem isegi lehm - siis läks kergemaks. Mõned noored said võimaluse elukutse õppimiseks.

Külas oli 4-klassiline kool ühe õpetajaga. Meie ei osanud vene keelt. Vaatamata sellele oli õpetaja nõus meid õpetama. Meid kogunes 8-10-aastaseid lapsi viisteist. Läksime kõik esimesse klassi. Ainult Jüri Pärg sai teise klassi, sest ta oskas natuke vene keelt. Vene lapsi oli vähem kui meid. Ema püüdis õpetajat abistada, aga kahjuks pidi ta metsatööl käima. Kõik me saime lugemise-kirjutamise selgeks ja kevadel viidi üle teise klassi. Jutustamisoskus tuli kolmandas klassis, teises õppisime veel kõik lihtsalt pähe.[---]

Asta Rohtla, lk 67-68

1942. aastal läks Endel seal 8-aastasena kooli. Mingeid tähti nad pidid seal õppima ja talle pandi nende täheridade eest hinne "otlitšno". Siis ei olnud hinnet "5" ja seetõttu ei teadnud 
ta, mis see tähendas. Muidugu vene keel sai neil ruttu selgeks. Kuna seal elas palju eestlasi, siis vene lapsed õppisid eesti keele ära ning nad ei saanud enam midagi salaja rääkida. [---]

Ema vene keele oskus tuli kasuks igapäevaelus. Kuna Endli ema vanused vene naised ei osanud ei kirjutada ega lugeda (sellele vaatamata olid nad ikkagi mõne aasta eest siia välja saadetud), kirjutas ema nende eest meestele sõjaväkke kirju, mille eest ta sai vastutasuks piima. Sellega ta oli vahendaja ning väga usaldatav inimene.

Kaks eesti naist pandi kinni, kuna nad laulsid jõululaule ning õpetasid vene poistele eesti keeles roppusi. Selle eest said nad 10 aastat laagrit ning ühe naise kaks last saadeti lastekodusse. [---]

Kargasokis lõpetas Endel 7.ja 8. klassi, Tomskis omandas auto-ja mootorrattaload ning tegi laevaradisti eksamid. Olgugi, et autojuhilubadega polnud midagi teha, kuna autosid ei olnud. Kaugõppes tegi vanemmehaaniku eksamid ning hakkas tööle sides ja poole kohaga kinos abimehaanikuna. Hiljem, kui vabanes, läks Leningradi raadiotehnikumi edasi õppima. [---]

Ükskord nad põgenesid Nedostupnõist. Enne jääminekut pani ema kõik kraami, mis neil oli, kelgule, Endel lükkas tagant ja ema vedas. Neil oli minna rohkem kui viis kilomeetrit poolpõiki üle jõe, sest talvel Nedostupnõi ei ole "nedostupnõi”, kuna siis katab jõge jää. Üks vana komandant nägi neid põgenemas ja tuli ratsahobusega taga ajama. Paraku hobune vajus läbi kevadise jä̈̈ ja komandandil oli tema väljatõmbamisega tegemist ning Endli perekonnal õnnestus silmapiirilt kaduda. Nad läksid just jäämineku ajal, aga 2-3 nädala jooksul ei saa üle jää mitte keegi mitte kuidagi. Neid ei hakatud ka hiljem taga otsima.

Endel Muuga, lk 53-54

1943. aastal tuli suur muudatus meie küla inimeste ellu. Rajooni keskusesse Aleksandrovkasse hakati ehitama kalakonservivabrikut ja inimesed värvati sinna tööle. Elati barakkides ja ehitati. Kalatsehh sai kiiresti valmis. Kord oli väga range ja mingit varastamist ei olnud. Kalarappeid, mis olid mõeldud äraviskamiseks, võis võtta. Sealt sulatati kalamaksaõli ning 
sisikondi praeti. Ka tööliste leivanorm oli suurem - 700 grammi päevas ning kord kuus sai 200 grammi suhkrut. [---] Aegajalt sai ema lisateenistust ómblemisega. Nü̈̈d oli ka keel selge, mis võimaldas suhelda ja õppida.

Neljas aasta on meelde jäänud rõõmsana ja lootusrikkana. Hakkasime kirjutama kodumaale ja enamikul oli ikka keegi alles, kes vastas. Hakkas tulema kirju ja pakke. Käidi koos ja lauldi "Ma tahaksin kodus olla" ja teisi laule. Loodeti, et varsti lõpeb sõda ja elu saab jälle korda.

Siis lõppeski sõda. Kõik juubeldasid ja olid täis lootusi. Sinna evakueerunud perekonnad hakkasid lahkuma. Meie suhtes ei tulnud mingisuguseid muudatusi.

Asta Rohtla, lk 67

Küüditatud ei pääsenud. Küladesse toodi uusi väljasaadetuid - hulga volgasakslasi ja teistest rahvustest inimesi, kes olid elanud Venemaa läänepoolsetel aladel sakslaste okupeeritud territooriumil ja suhelnud sakslastega. Nüüd karistati neid. See tähendas riigis ju jälle uusi küüditamisi.

\section{Lapsed koju}

1946. ja 1947. aastal hakati eesti noori lubama paarikaupa koju sõita. Komandandilt kuuldud seadus oli selline: kes Eestist väljasaatmise päeval (14. juunil 1941) ei olnud üle 15-aastane, võib kodumaale tagasi pöörduda. Ei olnud ühtegi ema, kes poleks oma lapsest või lastest raatsinud lahkuda, ükskõik kui valus see hingele oli. [---]

Esimesed noorimad minejad olid 7-8-aastased. Läbisid jalgsi $200 \mathrm{~km}$ Kirovi linnani, et sealt rongiga edasi pääseda. Rõomuga läksid kõik, kuid kõigil polnud ees ootamas loodetud rõõmu. Enamikul ei olnud enam kodu ja puudusid ju oma vanemadki.

Jõudsime Tallinna päeval, mil algas üldlaulupidu. Istusime oma pampudega trotuaari servale. Hea ülemus oli mu kaaslasele kinkinud kojusõidu eel kirsasaapad. Ilm oli soe ja päikesepaisteline, mistõttu mõnigi laulupäevalistest heitis meile iroonilisi pilke. Osavôtmatult jälgisin uhket rongkäiku, mille ees 
kõndis viltkaabus ja pikas mulgi kuues kaharpäine mees, kummagi käe otsas rahvariides poisike. Kuulsin selja taga öeldavat nime - Gustav Ernesaks. Korraga nägin transparenti, millele maalitud viikingilaev ja suurelt kirjutatud-Saaremaa. Kolonni ees tundsin ära meie hea perekonnatuttava, koorijuhi ja klaveriõpetaja Joosep Aaviku. [---]

Tallinnas peatusime väikeses majas Pärnu maanteel. Selle aadressi olid meile saatnud varasemad kojujõudnud. Need olid meile võhivõõrad inimesed Sohvi ja Mihkel, kes oma tillukeses toas võtsid vastu Venemaalt saabunud eestlasi ja andsid neile ajutist elamist. Tol ajal ei olnud piirikontroll nii range ja laulupeoliste hulgas jõudsime ka meie kauaigatsetud Saaremaale.

\section{Helvi Koppel, lk 81-82}

Kotipoisid Koloveres. Kirjutaja isiklikud mälestused hulkuvatest näljastest lastest ulatuvad 1944/45. aastasse. Olin siis 2. klassi õpilane, kui sõjaga koos ja sõja järel, Punaarmee jälgedes tuli Eestisse omapäi lõputult igast rahvusest näljaseid lapsi ja noori. Neid nimetati kotipoisteks. Neid toodi Kolovere (raskestikasvatatavate) lastekodusse Läänemaal, kus minu isa oli juhatajaks. Lastekodu 80 kohal elas varsti mitusada näljast kasvatamata ja koolitamata enamasti venekeelset last. Toidunormid olid väikesed. Nad varastasid ja sõid kõike, tegid meie juurviljakeldri tühjaks. Aga elasime meiegi tšekitoidust ega saanud neid aidata. Kolovere sai varsti valvuriteks püssimehed ja ülemuseks NKVD.

1946. aastal ilmus seadus, mis lubas lastel, kes kü̈̈ditamise hetkel ei olnud 16-aastased, lahkuda kodumaale. [---] Õppisime vend Adoga erinevates kohtades, üks ühe, teine teise tädi juures. Mina sain kodumaal olla kolm aastat, siis muudeti see seadus ning 1950. aastal viidi mind tagasi Siberisse samasse kohta, kust tulin. Vahepeal oli ilmunud ka seadus, mis keelas represseeritutel arstiabina töötamise. Ema, õppinud ja diplomiga hambaarst, vallandati sellelt kohalt. Õnneks sai ta meditsiiniõeks lastekodusse. Lastekodus hakkas ta ka lastele käsitööd õpetama.

Asta Rohtla, lk 68 
Seda, et elus olen, said lapsed, ema ja õed teada alles 1945. aasta kevadel. Inimesed olid mööda Eestit laiali. [---] Kui Narvas hakkas jälle tööle postkontor, nägi üks sugulane minu saadetud kirju ja hakkas otsima, kus mu omaksed on. Läbi mitme inimese jõudis kiri lõpuks Viru-Roelasse. Sellest ajast algas kirjavahetus. Enamik kirju oli kirjutatud pliiatsiga kasetohule; nii ka päevik. Aga kui 1954. juunis sain loa sõita mehe juurde Igarkasse - ta oli pärast vangilaagrit sinna asumisele saadetud - hakkasin päevikut põletama, sest kartsin seda teele kaasa võtta. Säilinud on aga palju laule, mis Siberis luuletati ja tuttavatel viisidel lauldi. Eestist viidi meid ära 14. juunil 1941. aastal. Igarkast hakkasime tagasi sõitma samuti 14. juunil kell 4.30 hommikul, aga 18 aastat hiljem, 1958. aastal.

Leida-Johanna Savi, lk 61

\section{Vabastamine}

Pärast Stalini surma (1953) hakkas kasvama lootus. Mõnel oli juba varem õnnestunud kodustega kirjavahetusse astuda ja vahel pakke saada. See oli lootus edasisele elule. Vabastamine tuli 50ndate lõpul. Vabastatud pidid andma allkirja, et ei taotle tagasi oma vara ega asu elama endisesse kodukohta Eestis.

Stalini surma mäletan selgesti. Olime just tule ääres, sulatasime oma väikesi leivatükke orgi otsas, et lõunat süüa. Oli ilus päikesepaisteline, aga väga külm ilm. Kõik metsaveotraktorid hakkasid signaali andma. Ülemus tuli meie juurde ja ütles, et Stalin on surnud. Oli neid, kes lõid kirved puutüve sisse ja nutsid, muidugi mitte keegi meie omadest. Meie muigasime habemesse ja tundsime heameelt. Eks meile igaühele läks südamesse midagi sellist, mida tohtis ainult mõelda, mitte aga välja öelda. Meie, eestlased, olime seal nagu üks pere. Olime väga lähedased üksteisele. Ei tea, et oleks mingit nääklemist või pahandusi olnud. Rohkem ikka aidati üksteist.

Kojutulek. 17. märtsil 1958 kutsuti meid komandantuuri ja loeti ette, et oleme vabad. Aga ei tohtinud minna tagasi oma kodupaika ja nõuda tagasi oma kodu ning varandust. Sellele dokumendile kirjutasime alla. Oli maikuu, kui vend sõitis Eestist meie juurde, et meid koju viia. [---] 
Aga ka siit ei leidnud ma eest mingit kodutunnet, sest mind ei tahetud sissegi kirjutada. Puudus elamispind. Abikaasa vend ja õde töötasid raudteel ja elasid vagunis, saime nende juurde elama. Elu vagunis talvel koos väikese lapsega ei olnud kerge, aga elada tuli. [---]

Kirjutasime ju Siberis alla, et ei nõua oma kodu ega vara. Meie sünnikodu oli alles, aga seal elasid meie sugulased ja neil oli hea meel, et me ei nõudnud oma kodu tagasi.

Elvi Vokk, lk 37

1953. aastal suri Stalin, siis hakati inimesi vabastama. Mulle öeldi, et minu vabastamise aeg on 1958. aastal. Hiljem selgus, et see oli viga - mul on isegi dokument olemas, kus on kirjas, et mind vabastati 1953. aastal, aga keegi ei öelnud mulle seda. Nii olingi Siberis veel viis aastat. Passi sain ja tagasi tulin 1958. Iga kolme aasta tagant pandi meile lasteaias $30 \%$ palka juurde, nii et vabastamise ajaks oli mul mingi raha juba kogunenud. Enne ärasõitu imestas lasteaia juhataja: "Ilse Jakovna, te teenite ju nii hästi, miks te ära sõidate?" Vastasin talle, et hauda ei võta ma ju midagi kaasa, tahan koju minna. Tõmme Eestisse tagasi tulla oli väga suur. [---]

Pärnus olen tagasitulemisest saadik ikka üksi elanud.

\section{Ilse Kotter, lk 49}

Eesti noored osalesid aktiivselt isetegevuses. Kohalikud elanikud ootasid alati eestlaste esinemisi. 1953. a märtsi esimestel päevadel läksime rajoonikeskusesse isetegevusfestivalile esinema. Kuigi Nagorskisse oli üle 80 kilomeetri, olime seda teed käies rõómsad, et taoline võimalus üldse avanes. Rajooni kultuurimaja oli puupüsti rahvast täis, isegi igast aknaruudust vaatas mitu nägu. Näidend oli põnev ja aplausi palju koos igat laadi vahelehüüetega. Hoolimata hoogsast peost olid kohalikud asjamehed üpris tõsised, mõned isegi nutsid. Pidevalt käidi ühes suletud ruumis telefoniga rääkimas. Sosinal liikus ringi kuuldus, et Stalin on raskesti haige. Siiski anti meile luba oma tantsud esitada, kuna publik vilistas ja trampis jalgu ning keegi ei nõustunud saalist lahkuma. Pärast õnnestunud esinemist nägime kultuurimaja ja rajooni juhtivaid töötajaid 
murest murtud nägude ning nutetud silmadega - Stalin oli surnud. Meile, eestlastele anti korraldus kohe samal hilisõhtul rajoonikeskusest lahkuda. Oli selge täiskuuöö. Meie elu aga kulges muudatusteta. [---]

1956. aastal hakati eestlastele passe välja andma ja sama aasta sügisel sõitsin Eestimaale. Veel ei tohtinud olla rahu hinges. Suur oli kibestumine, kui see kodu keeldus andmast mulle tööd. Pärast nädalast töötamist kombinaadis Järvakandi Tehased (klaasivabrik) kutsuti mind kaadriosakonda, kus öeldi, et Vändrast, rajoonikeskusest tuli korraldus minu töölt vabastamiseks. Minu mehele öeldi, et oleksite pidanud mõtlema, KELLEGA abiellute! Ei osanud ega julgenud abi saamiseks kellegi poole pöörduda. Aastaid hiljem leidsin kombinaadi arhiivist sellele vastuse: lahkus töölt omal soovil! Olin valmis sõitma tagasi koduseks saanud Kirovi linna, isegi kutse oli sealt olemas. Väga raske oli olla lindprii oma sünnimaal. Kuid bürokraadist ametnikku hakkas asendama mõtlev inimene ja aasta pärast olukord normaliseerus. Üksteise järel saabusid Eestisse ka õed ja vend ning lõpuks ka ema. Selline oli meie pere lugu.

Helvi Kohandi-Koppel, lk 82-83

Paljudele jäi must plekk eluajaks. Isegi pärast kõrgkooli edukat lõpetamist ei olnud võimalik saada haridusele ja võimetele vastavat vaba töökohta, räägib Asta Rohtla oma vennast Adost, kellele jäi elu lõpuni hinge sügav haav. Need Siberi-aastad varjutasid kogu tema edaspidise elu. Ikka ja jälle tuletati meelde, et olid Siberisse küüditatute hulgas. 14. juuni oli Ado jaoks kurb leinapäev.

Mälestustes tehakse ka kokkuvõtteid ja arutletakse küüditamise põhjuste, võõrastes tingimustes kohanemise ja ellujäämise üle. Küüditamine õpetas paljudele ellujäämise ja kohanemise kunsti.

\section{Kohanemine. Ellujäämine}

Esimesel kahel aastal surid ära kõik need, kes nari peal ohkasid, et mis saab, mis saab, kuidas ma koju saan jne. Elujõulisemad inimesed, kes tegid heina ja puid, jäid ellu. Surdi ära eeskätt sellepärast, et langeti masendusse ja oldi ükskõiksed. 
Näiteks Kaaveri proua, Võru kõige rikkama kaupmehe naine, istus naril, kiigutas ennast ja nuttis vahetpidamata. Talle toodi sü̈̈a ja hoolitseti, kuid siiski ei pidanud ta kaua vastu. [---]

Siberist tulid eelkõige tagasi need, kes olid võimelised eluga kohanema. Tugevaid eestlasi ei suudetud murda. Seal ópiti tundma elu karmimaid külgi ning osati hakkama saada reaalsusega.

Endel Muuga, lk 52, 55

Igas kirjapanekus on ühed või teised momendid küüditamise üle elanud lapse või nooruki jaoks kõige olulisemad. Mälestustes need korduvad. Lisaks esitatud katkenditele toon siin paljusid mälestusi läbivaid märksõnu.

\section{Märksõnad}

Lahkumine kodunt - Läbiotsimine - Küüditajad - Mehed eraldi - Reis/sõit Siberisse - Rahvused segi - Laps(ed) Eestisse

Sõda - Uus elukoht. Elutingimused - Korduv küüditamine, ümberasumised - Vahekord külarahvaga / kohalikega

Nälg - Surm(ad) - Toitlustamine - Lapsed kerjama

Töö - Kaebamine - Kontrollimine - Vene keele oskus

Külade ja kolhooside nimed - Oma põllulapp - Eestlaste käsitöö, töö kvaliteet - Kool - Ameti õppimine

Sõja lõpp - Kirjad ja pakid kodumaalt - Laste kojutulemine

Stalini surm - Salaja kodumaal - Tagasi Siberisse - Vabastamine / Vabanemine - Kodumaa ei võta vastu

Laul - reipuse ja elujõu allikas - Küüditamise põhjus - Küüditamisest pääsemine - Kohanemine. Ahastus. Ellujäämine

Küüditamisest teab rääkida peaaegu iga eesti pere. Rohkem kui 1941. aastat mäletatakse kaheksa aastat hilisemat küüditamist (1949). Siis viidi rohkem rahvast, ka mälestusi on rohkem. Teisel küüditamislainel langes raskuspunkt maarahvale ja perekonnad viidi koos - kui keegi perest enne juba kusagil vanglas või välismaal polnud. 


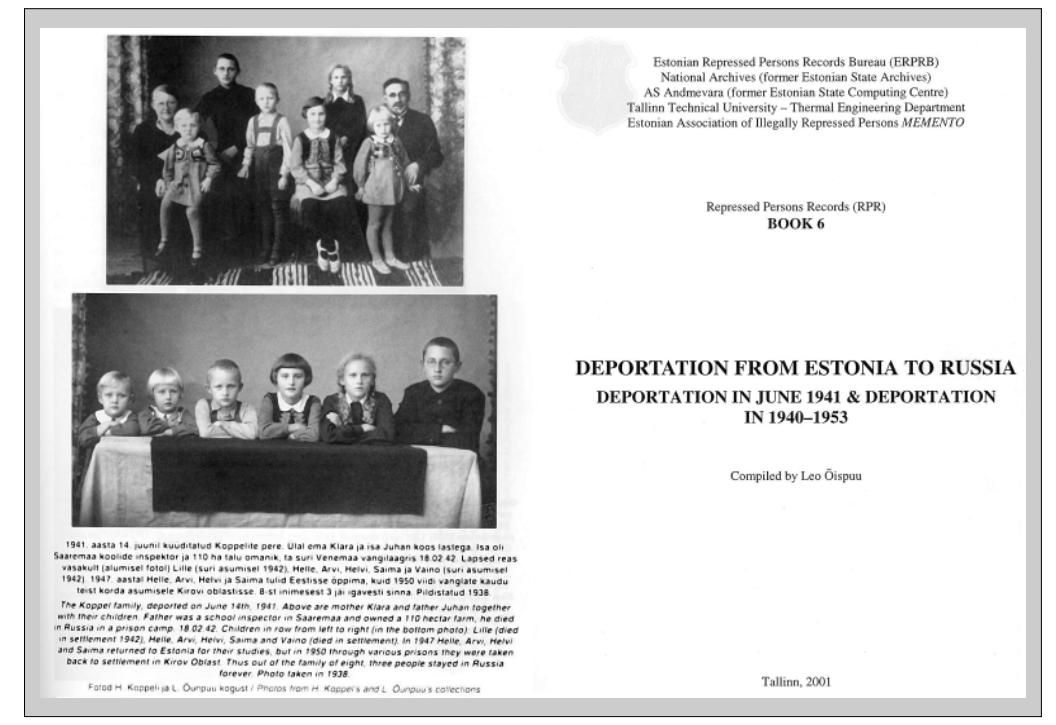

Ühenduse "Memento" ettevõtmisel on koostatud ja avaldatud hulk küüditatute ja hukkunute nimestikke ja statistikaid (vt nt Õispuu 1999, 2001; Varju \& Vessik 2002; Krepp 1981; Ruusmann 1990; Paavle 2002). Enamik 1940ndatel küüditatutest on 90ndatel rehabiliteeritud. Vähesed nendest said sellest teada elavana. Meie materjaliks on jutustused ja mälestused, rahva emotsioonid - ajaloo, etnoloogia, psühholoogia abimaterjal.

Viimasel kümnendil on kodu-Eestisse jõudnud või/ja siin ilmunud paljude väliseestlaste mälestusi. Need on lood põgenemistest üle Läänemere Rootsi ja Soome või vägisi viimistest maad mööda Saksamaale tööle. Need on jutustused kodumaa kultuurielu jätkamisest enamasti Saksamaa põgenikelaagrites 1944. aastast alates: asutati koole, anti välja ajalehti, tegutseti näiteringides ja laulukoorides. Edaspidi võeti eestlasi vastu mitmetes heatahtlikes maades, kus tekkisid tugevad ja siiani tegutsevad eestluse keskused, - Saksamaal, Rootsis, Kanadas, Austraalias, Suurbritannias, USAs jm (Kool 1999).

Omaette jutustuste ja mälestuste valus teema on 19. sajandil ning 20. sajandi algul Venemaale asunute järeltulijate nn venemaa-eestlaste tagasipöördumine Eestisse. Nõukogude valitsus usaldas pärast 
sõda vene keelt oskavaid venemaa-eestlasi kohalikest rohkem ja määras neid sageli väiksema hariduse, ent poliitilise ustavuse järgi kõrgematele töökohtadele. Siinsed eestlased umbusaldasid saabujaid - ja sageli põhjusega. Venemaa vähemusrahvuste 1930ndate aastate repressioonid, hukkamised ning sõda olid teinud oma töö aktiivsetest eestlastest olid alles (loe: ellu) jäänud parteile ustavad inimesed. Nad pidid mõnikord isegi oma eesti keele oskust varjama, et parteiseltsimeestele kohaliku rahva meelsusest ettekandeid teha. Mitu põlve Venemaal elanud ja venekeelse hariduse saanud inimesed ei rääkinud ka enam puhast emakeelt, aga eesti keel ja keeleoskus on meie väikesele rahvale alati väga tähtis olnud.

Kui Läände elama asunud 1960ndatest alates said võimaluse kodumaad külastada - küll range kontrolli ja registreerimise tingimustes, esialgu ainult Tallinnas, - leidsid nad eest hoopis teistsuguse Eesti, kui omal ajal põgenedes maha oli jäänud. Ühed arvasid eest leidvat ikka veel põlevad linnad ja püssipaugud, teised igatsesid nostalgiliselt rahulikku iseseisvat Eesti Vabariiki. Siin polnud kumbagi. Elada tuli võõra võimu ja seaduste all.

Oleme jälginud ka Läände siirdunuid (väljarändajaid ja -saadetuid) nende mälestuste, jutustuste ja intervjuude kaudu viimase vaba kümnendi jooksul. Uurijad on märkinud Itta ja Läände siirdunud/saadetud inimeste tingimuste ja ootuste erinevusi.

Läände siirdunutel oli parem ettekujutus oma staatusest ja võimalustest, ka põgenikelaagris, kus siiski valitsesid mingid reeglid. Idas oli pikka aega vaid teadmatus - kaos, nälg ja surm. Läänes adapteeruti juba teise põlvkonna jooksul ja noored kohanesid hästi, nagu on järeldanud sotsioloog Aili Aarelaid (Aarelaid 2001)

Meie puutume Eestis praegu kokku veel teistsuguste mälestustega, ümberasumis- ja adapteerumislugudega, mida mõnigi veel praegu keeldub jutustamast: sajad tuhanded venekeelsed inimesed tulid siia pärast sõda heategijate ja valitsejatena. Vabanenud Eestis osutusid nad nõukogude mõttelaadiga muukeelseteks, kes arvasid enestel olevat vaid õigused, ent mitte kohustusi.

On huvitav võrrelda meeste ja naiste Siberi-mälestusi. Meeste omad, kuigi neid on vähem, on asjalikumad, täpsemad ja konkreetsemad, pikemad, kirjeldavad töid ja tööriistu, täpsustavad olukordi, toovad võrdlusi. 
Naised panevad rohkem rõhku meeleoludele ja emotsioonidele, inimeste vahekordadele, üksteise abistamisele. Mõlemate Siberimälestustes on väga täpselt fikseeritud kohanimed ja asukohad, lõputud rännud ühest paigast teise.

Maailmas on mitmeid eri aegadel asutatud eesti keskusi. Mitmete side kodumaaga tekkis enne Eesti vabanemist. Paljud väliseesti ettevõtmised (organisatsioonid, ajalehed, liidud) on oma missiooni lõppenuks lugenud ja mitmed on ühinenud kodu-Eestiga. Siit tulevad uued, kodu-Eestiga liitumise jutustused ja mälestused. Siit tulevad uued raamatud.

Iga põlvkond vajab oma ajalookäsitlust, vastavalt teadmistele ja üleelamistele, mõnekümne aasta järel uuesti. Mälestused ja elulood - nende hulgas ka 1941. aasta Siberi-mälestused-küüditamislood - on tähtis ja emotsionaalne materjal, täiendus ja lisa. See on ajalugu ja poliitika elulugude, jutustuste ja isiklike mälestuste kaudu.

Öösel vaevlen unes -

Näen teid olevat kodus,

Aga te hauadju

Venemaa lumes.

Ega see olnudki unes,

Et te hauad on

Venemaa lumes...

(1994)

Helvi Kohandi-Koppel, lk 75

\section{Kirjandus}

Aarelaid, Aili 2001. Kaks mudelit eestlaste kohanemisel Teise maailmasõja tagajärjel aset leidnud kultuurireaalsuse kontekstuaalsete muutustega. Kultuur ja mälu. Studia ethnologica Tartuensia 4. Tartu: Tartu Ülikooli Kirjastus, lk 174-197.

Eesti Elulood 1997a = Karusoo, Merle (koost). Kured läinud, kurjad ilmad. Tartu: Eesti Kirjandusmuuseum \& Ühendus Eesti Elulood \& Maalehe raamat. 
Eesti Elulood 1997b = Annuk, Eve (koost). Naised kõnelevad . Tartu: Eesti Kirjandusmuuseum.

Eesti Elulood 1999 = Hinrikus, Rutt (koost). Me tulime tagasi . Tartu: Eesti Kirjandusmuuseum.

Kiaupa, Zigmantas \& Mäesalu, Ain \& Pajur, Ago \& Straube, Gvido 1999. Geschichte des Baltikums. [Tallinn:] Avita.

Kippar, Pille 1998. Sõja-aastate kaotusi ja võite eesti etnoloogias. Kirme, Kaalu \& Kirme, Maris (toim). Kultuur Eestis sõja-aastail 1941-1944= Culture in Estonia during World War II 1941-1944. Acta Universitatis Scientiarum Socialium et Artis Educandi Tallinnensis: A, Humaniora 10 $=$ Tallinna Pedagoogikaülikooli toimetised:A, Humaniora $10=$ Proceedings of the Tallinn University of Social and Educational Sciences: A, Humaniora 10. Tallinn: Tallinna Pedagoogikaülikool, lk 90-103.

Kippar, Pille 2001. Tiefgreifende Umwälzungen in der Ethnologie Estlands in der vierziger Jahren des 20. Jahrhunderts. Seilenthal, Tõnu \& Nurk, Anu \& Palo, Triinu (toim). Dissertationes sectionum: Folkloristica \& Ethnologia: 7.-13. 8. 2000 Tartu. Congressus Nonus Internationalis FennoUgristarum VII. Tartu: [Eesti Fennougristide Komitee], lk 83-87.

Kool, Ferdinand (koost) 1999. DP Kroonika: Eesti pagulased Saksamaal 1944-1951. Lakewood (New Yersey): Eesti Arhiiv Ühendriikides.

Krepp, Endel (koost) 1981. Mass Deportations of Population from the Soviet Occupied Baltic States: On the Occasion of the 40th Anniversary of first Deportations of Estonians, Latvians, and Lithuanians. Stockholm: Estonian Information Centre \& Latvian National Foundation.

Kulu, Hill 1992. Eestlased maailmas: Ülevaade arvukusest ja paiknemisest. Diplomitöö. Käsikiri. Tartu: Tartu Ülikooli majandusgeograafia kateeder.

Paavle, Indrek (koost) 2002. Eesti rahvastikukaotused II: 1: Saksa okupatsioon 1941-1944: Hukatud ja vangistuses hukkunud = Population losses in Estonia II: 1: German occupation 1941-1944: Executed and died in prison. Eesti rahvastikukaotused okupatsioonide perioodil $(1940-1991)=$ Population losses in Estonia during foreign occupations (1940-1991). ORURKi (Okupatsioonide Repressiivpoliitika Uurimise Riiklik Komisjon) väljaanne 17 = ORURK publications 17. Tartu: Okupatsioonide Repressiivpoliitika Uurimise Riiklik Komisjon.

Raag, Raimo 1999. Eestlane väljaspool Eestit: Ajalooline ülevaade. Tartu: Tartu Ülikooli Kirjastus.

Ruusmann, Ants \& Möldre, Leili \& Larin, Peeter 1990. Ülevaade Eesti uusajaloost II. Tallinn: Eesti NSV ühing Teadus.

Salo, Vello (koost) 1993. Kü̈̈ditatud, 1941: Üldnimestik Tartu Instituudi arhiivis ja arhiivraamatukogus (Torontos) ning Eesti Represseeritute Registri 
Büroos (Tallinnas) leiduva andmestiku põhjal seisuga 24. veebruar 1993. Toronto: Maarjamaa.

Vaikimise väraval 2001 = Mõisnik, Krista \& Helme, Eneken (toim) \& Hinrikus, Rutt (eessõna). Vaikimise väraval : kooliõpilaste kogutud mälestusi küüditamisest:[Vabariigi Presidendi ajaloomälestuste võistluse töid]. Tallinn: Tänapäev.

Varju, Peep \& Vessik, Juta (koost) 2002. Saaremaa inimkaotused saksa okupatsiooni ja teise Nõukogude okupatsiooni aastail 1941-1953. [Kuressaare]: Saare Maakonna Memento Ühendus.

Viikberg, Jüri (koost ja toim) 1999. Eesti rahvaste raamat: Rahvusvähemused, -rühmad ja-killud. Tallinn: Eesti Entsüklopeediakirjastus.

Õispuu, Leo (koost) 1999. Küüditamine Eestist Venemaale: Märtsiküüditamine 19492 = Deportation from Estonia to Russia: Deportation in March 1949 2. Represseeritud isikute registrid (RIR) 5 = Repressed Persons Records (RPR) 5. Tallinn: Eesti Represseeritute Registri Büroo.

Õispuu, Leo (koost) 2001. Kü̈̈ditamine Eestist Venemaale: Juuniküüditamine 1941 \& kü̈̈ditamised 1940-1953 = Deportation from Estonia to Russia: Deportation in June 1941 \& Deportation in 1940-1953. Represseeritud isikute registrid (RIR) $6=$ Repressed Persons Records (RPR) 6. Tallinn: Eesti Represseeritute Registri Büroo. 